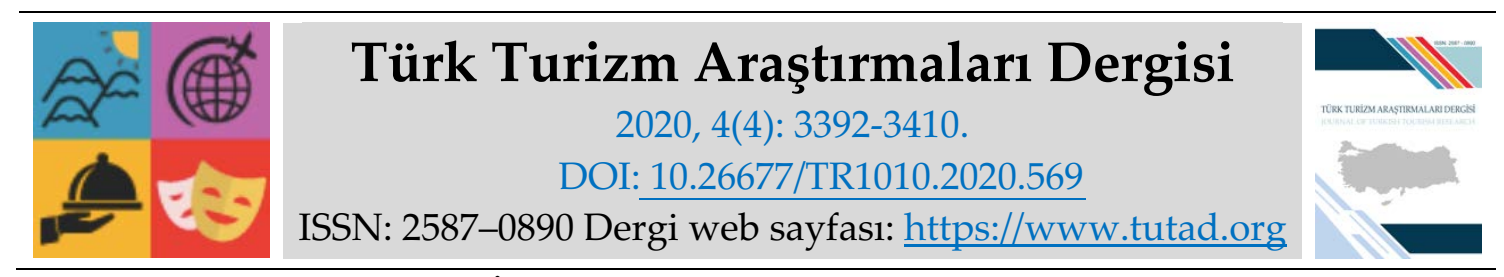

ARAȘTIRMA MAKALESI

\title{
Destinasyonlarda Mültecilere Yönelik Algıların Davranışsal Niyete Etkisini Belirlemeye Yönelik Bir Araştırma*
}

Öğr. Gör. Dr. Metin SÜRME, Gaziantep Üniversitesi, Turizm ve Otelcilik Meslek Yüksekokulu, Gaziantep, e-posta: surmemetin@gmail.com

ORCID: https://orcid.org/0000-0001-9810-7073

Doç. Dr. Ahmet TAN, Gaziantep Üniversitesi, İktisadi ve İdari Bilimler Fakültesi, Gaziantep, eposta: tan@gantep.edu.tr

ORCID: https://orcid.org/0000-0001-9972-4372

Öz

Gerçekleştirilen bu araştırmada destinasyonlarda mültecilere yönelik algıların destinasyona yönelik kişilik imaj, tutum, memnuniyet ve davranışsal niyete etkisi ortaya konmuştur. Gaziantep ilini ziyaret eden ve en az bir gece konaklayan 503 turistten kolayda örnekleme yöntemi ile veriler toplanmıştır. Araştırma sonucunda elde edilen nicel bulgularda ise mültecilere yönelik algının, destinasyona yönelik memnuniyeti ve kişiliği negatif yönde etkilediği görülmüştür. Araştırma sonuçları genel olarak değerlendirildiğinde; mültecilere yönelik algının, destinasyona yönelik memnuniyeti negatif yönde etkilemekte olduğu görülmüştür. Araştırmada dikkat çeken diğer bir bulgu ise mültecilere yönelik algının davranışsal niyeti etkilememesidir. Memnun olmayan bir turistin davranışsal niyetinin de teorik olarak olumsuz olması beklenmektedir. Ancak burada mültecilere yönelik algının davranışsal niyeti etkilemediği sonucu görülmüştür. Dolayısıyla mültecilerin varlığının destinasyona gelme niyetinde etkili olmadığı ancak memnuniyeti olumsuz etkilediği gerçekleştirilen bu araştırmayla ortaya konmuştur.

* Bu çalışma "Gaziantep Üniversitesi tarafından desteklenmiştir." Bununla beraber Gaziantep Üniversitesi Sosyal Bilimler Enstitüsü, İşletme Ana Bilim Dalı'nda hazırlanan “Destinasyonlarda Mültecilere Yönelik Algıların Destinasyona Yönelik Kişilik, İmaj, Tutum, Memnuniyet ve Davranışsal Niyete Etkisi" isimli doktora tezinden türetilmiştir.

Anahtar Kelimeler: Mülteciler, Destinasyon, Turizm, Gaziantep.

Makale Gönderme Tarihi: 24.05.2020

Makale Kabul Tarihi: 03.10.2020

\section{Önerilen Atıf:}

Sürme, M. ve Tan, A. (2020). Destinasyonlarda Mültecilere Yönelik Algıların Davranışsal Niyete Etkisini Belirlemeye Yönelik Bir Araştırma, Türk Turizm Araştırmaları Dergisi, 4(4): 3392-3410. (C) 2020 Türk Turizm Araştırmaları Dergisi. 


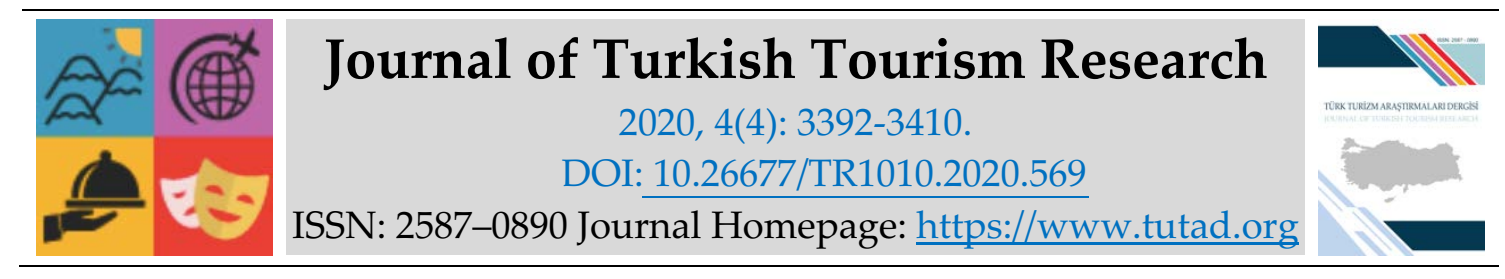

\title{
$\underline{\text { RESEARCH PAPER }}$
}

\section{A Research to Determine the Effect of Perceptions of Refugees on Behavioral Intent in Destinations}

Dr. Metin SÜRME, Gaziantep University, School of Tourism and Hotel Management, Gaziantep, e-mail: surmemetin@gmail.com

ORCID: https://orcid.org/0000-0001-9810-7073

Associate Prof. Dr. Ahmet TAN, Gaziantep University, Faculty of Economics and Administrative Sciences, Gaziantep, e-mail: tan@gantep.edu.tr

ORCID: https://orcid.org/0000-0001-9972-4372

\begin{abstract}
This study investigates the impact of perceptions towards refugees in tourist destinations on the personality, image, attitude, satisfaction and behavioral intention regarding the destinations. Data was collected through convenience sampling method from 503 tourists who visited Gaziantep and stayed for at least one night. A general evaluation of the study results indicated that the perceptions about refugees negatively affect satisfaction with the destinations. Another prominent finding in the study is that perceptions about the refugees do not affect behavioral intention. However, it has been seen that perceptions about refugees do not affect behavioral intention. Therefore, this study has revealed that the existence of refugees does not affect an intention to visit a destination, yet it negatively affects satisfaction.
\end{abstract}

Keywords: Refugees, Destination, Tourism, Gaziantep.

Received: 24.05 .2020

Accepted: 03.10.2020

\section{Suggested Citation:}

Sürme, M. and Tan, A. (2020). A Research to Determine the Effect of Perceptions of Refugees on Behavioral Intent in Destinations, Journal of Turkish Tourism Research, 4(4): 3392-3410.

(C) 2020 Türk Turizm Araştırmaları Dergisi. 


\section{Gíriş}

Daha güzel bir yaşam sürdürme isteği ve beklentisiyle kendi ülkeleri dışında başka bir ülkede yaşamak üzere göç hareketine katılarak yeni bir hayata başlayan insanların sayısı son yıllarda dikkat çekici biçimde artmaktadır (Özgüneş, Açıksözlü ve Bozok, 2016). 21. yüzyılda gerçekleşen göçler, bir tercih değil zorunluluk şeklinde ortaya çıkmaktadır. Başka bir ifadeyle göç, yerinden olmaya veya edilmeye karşılık gelmektedir (Kara ve Korkut, 2010:154). Göç, genel itibari ile itme ve çekme olmak üzere iki ana faktör tarafından etkilenmektedir. İten faktörler; savaşlar, açlık, siyasal ya da dini baskı, yüksek enflasyon, düşük ücretler ve durgun ekonomik koşullar olurken, çeken faktörler ise iyi iş, yüksek ücret, iyi eğitim, çekici çevre, dinsel özgürlük, aileye yakınlık şeklinde ortaya çıkmaktadır. Bunun yanı sıra farklı grupların göç eğilimleri; yaşa, cinsiyete, medeni duruma ve kişisel özelliklere göre de değişim gösterebilmektedir (Özgüneş, Açıksözlü ve Bozok, 2016).

Arap Baharı, işlerin kötüye gittiği acil durumun başlangıcı olmuştur. Başka bir ifade ile Arap Baharı olarak yerini alan ve sonuçlarından tüm dünyanın, özellikle de Avrupa'nın derinden etkilendiği kriz ile bir taraftan Orta Doğu ve Kuzey Afrika ülkelerinde köklü değişiklikler yaşanmış diğer taraftan birçok insanın ölümü ve ülkelerini terk etmeleri konusu dünyanın gündemine oturmuştur. 2015 yılında, Avrupa'ya ulaşan veya ulaşmaya çalışan göçmen sayısı, İkinci Dünya Savaşı'ndan bu yana yaşanan en büyük göç krizinin patlamasına neden olmuştur (Akdoğan ve Sağıroğlu, 2017). Göçe tarihsel, coğrafik ve toplumsal olarak aşina olan Türkiye'de, yasadışı göçlerden de nasibini almıştır (Kara ve Korkut, 2010:154). 2011 yılı Mart ayında Suriye'de başlayan protestolar ve Suriye hükümetinden gelen baskılar Suriye'de bir iç savaşın habercisi olmuş bu durum da birçok Suriyelinin ülkesini terk etmesini ve başka ülkelere göç etmesinin önünü açmıştır (Akdoğan ve Sağıroğlu, 2017).

Türkiye coğrafi konumu, demokrasisi, siyasi istikrarı ve ekonomisinin gelişmiş olması sebebiyle yabancı uyruklu kişileri cezbeden ülke haline gelmiştir. Arap Baharı ile başlayan gelişmeler ve 2011 yılında Suriye' de yaşanan iç sorunlar nedeniyle Türkiye' de mülteci sayısında artış yaşanmış ve öyle ki Türkiye 2014 yılından bu yana dünyanın en fazla mülteci barındıran ülkesi haline gelmiştir. 23 Mayıs 2019 tarihi itibarıyla İçişleri Bakanlığı Göç İdaresi Genel Müdürlügü verilerine göre Geçici Koruma Kapsamında toplam 3 milyon 608 bin 049 Suriyeli mülteci bulunmaktadır (İçişleri Bakanlığ1 Göç İdaresi Genel Müdürlüğü, 2019).

Komşu ülkede iç savaş sürerken ve mülteciler ülkeye gelirken Gaziantep şehri Birleşmiş Milletler Eğitim, Bilim ve Kültür Örgütü'nün (UNESCO) Yaratıcı Şehirler Ağına girmeyi başarmış ve gastronomi başkenti olarak bir marka şehir olma yönünde ilerlemektedir. Dolayısıyla oldukça kritik bir süreçte, Gaziantep mülteci sorunu ile yüz yüze kalmıştır. Bu süreçte mültecilerin turizme etkilerinin ortaya konması pratikte oldukça önem taşımaktadır. Gerçekleştirilen bu araştırma ile mültecilerin turizme etkisinin ortaya konması ve turizm işletmelerine bu konuda öneriler getirilmesi sebebiyle önem taşımaktadır. Bununla beraber ilgili literatürde mültecilerin turizme etkisini ortaya koyan sınırlı sayıda araştırma olduğu görülmüştür. Dolayısıyla gerçekleştirilen bu araştırmanın teorideki bu eksikliğe katkı sunacağı düşünülmektedir.

\section{LITERATÜR TARAMASI}

Mülteci sorunu 21. yüzyılda tüm dünyanın ortak sorunu olarak görülmektedir. İlgili literatür incelendiğinde (Endrich ve Michel, 2018; Ivanov ve Stavrinoudis, 2018; Zenker, Von Wallpach, Braun ve Vallaster 2019) mültecilerin uyum süreci, kültürlerinin entegrasyonu, istihdama olan 
etkileri gibi birçok alanda çalışmalar gerçekleştirildiği görülmektedir. Ancak mültecilerin destinasyona olan etkisi bu noktada ihmal edilmektedir. Bu kapsamda gerçekleştirilen bu araştırmada destinasyonlarda mültecilere yönelik algıların destinasyona yönelik kişilik, imaj, tutum, memnuniyet ve davranışsal niyete etkisi incelenmiştir.

Mülteci tanımının ortaya çıkması, insanların yaşam ve özgürlük alanlarına müdahale edilmesiyle başlamaktadır. 1951 tarihli Cenevre Sözleşmesi'nde mülteci, "terk ettiği ülkesine geri dönmesi durumunda özgürlüğü ve yaşamı tehlikede olacak kişidir" şeklinde tanımlanmaktadır. Mültecinin terk ettiği ülkesine dönme olasılığının olmaması gerekmektedir (Kavuk, 2015, 187189). 18 Aralık 2010 tarihinde pazarcılık yapan bir üniversite mezununun tezgâhına el konulması sonrası kendisini protesto için yakmasıyla Tunus'ta başlayan "Arap Baharı'nın estirdiği "Demokrasi Rüzgârı" Suriye'yi derinden etkilemiş ve halkların büyük bedeller ödemesine neden olmuştur. İç savaş, yoksulluk, terör ve siyasi baskıların etkisi altında birçok insan ülkesinden kaçarak özellikle Avrupa'ya yönelmiş ve Akdeniz üzerinden ölüm riskini göze alarak deniz yolculuğu gerçekleştirmiştir (Akdoğan ve Sağıroğlu, 2017:147).

Arap baharıyla beraber başlayan Suriye'de de 2011 yılında rejime karşı başlatılan ayaklanma, çatışmaya dönüşmüş̧ür. Suriye' de son yıllarda yaşanan çatışmalar sonucu ortaya çıan sorunlar uluslararası medyada en çok üzerinde durulan konuların başında gelmektedir. 2011 yılında rejime karşı başlatılan ayaklanma şiddetini giderek artırmış ve başta mülteci krizi olmak üzere birçok sorunu beraberinde getirmiştir. Bunun sonucunda dünya genelinde hemen hemen her ülke göçten etkilenmiştir. Özellikle 20 yüzyılın ikinci yarısı toplu nüfus hareketlerine şahitlik etmiştir. Nitekim son 50 yıllık dönemde 175 milyondan fazla insanın kitlesel olarak göç ettiği bilinmektedir. 2013 Birleşmiş Milletler (BM) küresel göç verilerine göre dünya üzerinde 232 milyon kişi, yani dünya nüfusunun yüzde 3,2'si, göçmenlerden oluşmaktadır (İç İşleri Bakanlığ Göç İdaresi Genel Müdürlüğü, 2013).

Türkiye'nin jeopolitik konumunun neden olduğu göç gibi olumsuzluklar, Türkiye ekonomisindeki her sektörü etkilediği gibi turizm sektörünü de etkilemiş ve sektörde krizlerin yaşanmasına neden olmuştur. Özellikle Suriyeli sığınmacı sayısının artması Türkiye'yi farklı yönlerden etkilemiş̧ir. Ancak Suriyeli mülteci sorunu, siyasi, ekonomik, güvenlik, hukuki, toplumsal boyutlarının yanı sıra turizm yönü ile de değerlendirilmesi önem taşımaktadır. Diğer taraftan Türkiye'nin üç tarafının denizlerle çevrili olması, temiz plajlara sahip olması, birçok medeniyete ev sahipliği yapması, köklü mutfak kültürünün olması uluslararası alanda çekiciliğini artırmaktadır. 1982 Turizm Teşvik Yasası ile beraber yaşanan gelişmeler; ekonomik, sosyal ve kültürel alanlarda Türk turizmine önemli katkı sağlamıştır. O günden bugüne Türkiye turizmde önemli gelişmeler göstermektedir.

Turistler, destinasyon seçimlerine karar vermeden önce gidecekleri destinasyon hakkında birtakım kaynaklardan bilgi edinmektedir. Eğer turist gideceği destinasyonu daha önce ziyaret etmemiş ise edindiği bu bilgiden büyük ölçüde etkilenmektedir. Bu bağlamda mültecilerin, yaşadıkları ve yaşattıkları sorunlar hem ulusal hem de uluslararası basında yer almakta ve bu haberlerin seyahat kararını veren insanların destinasyon hakkındaki tutumunu etkileyebileceği düşünülmektedir (Aratimur ve Akgündüz, 2018:158). Türkiye'de sayıları her geçen gün artan Suriyeli mülteciler turizm endüstrisinde de yeni planlamaların yapılmasını gerekli kılmaktadır. Özellikle turizm alanının "estetik, huzur ve güven" alanı olduğunu vurgulayan sektör yetkilileri, kayıpların önüne geçmek amaciyla mülteciler konusunda planlamaya ihtiyaç olduğunu belirtmektedir. Mülteci kavramına yönelik gerçekleştirilen araştırmaların daha çok mültecilerin sosyo-ekonomik durumu, statüleri, eğitim durumları gibi konulara odaklandığı görülmektedir. 
İlgili alan yazında mültecilerin destinasyon imajına, kişiliğine, tutuma, memnuniyete ve davranışsal niyet üzerindeki etkilerini araştıran araştırmaya rastlanılmamıştır. Ancak mültecilerin turizm endüstrisine etkilerini araştıran sınırlı sayıda araştırmanın olduğu görülmüştür (Aratimur ve Akgündüz, 2018; Zenker, vd., 2019). Destinasyonlarda mültecilere yönelik algı kavramına yönelik gerçekleştirilen araştırmaların özetleri ise aşağıda gösterilmiştir.

Zenker vd., (2019), mülteci krizinin turistlerin karar yapısını nasıl etkilediğini incelemek amacıyla Avusturya, Almanya, İngiltere ve ABD'de 2612 kişi üzerinde bir araştırma gerçekleştirmiştir. Araştırma sonucunda mülteci krizinin, turist davranışını ve destinasyon imajını etkilediği görülmüştür. Bununla beraber Pappas ve Papatheodorou (2017), mülteci krizinin turizm üzerindeki etkilerini incelemek amaciyla Yunanistan'da 811 konaklama işletmesi yöneticisi üzerinde bir araştırma gerçekleştirmiştir. Araştırma sonucunda turist eylemleri boyutuna bakıldığında "Yunanistan'ı ziyaret eden turistler, destinasyon hakkında başkalarına olumsuz şeyler söyleyebilir" ifadesinin en düşük ortalamaya sahip olduğu görülmüştür. Bununla beraber mülteci krizini işlerini tehdit olarak algılamak yerine operasyonel eylemlerini mülteci yanlısı bir bakış açısı içerisi ile içinde düzenlemeleri gerektiği önerisinde bulunmuşlardır. Başka bir ifade ile mülteci krizini; çeşitlilik, hoşgörü ve merhamete dayanan bir konukseverlik kültürünü teşvik etmek için bir fırsat olarak kullanılması gerektiğinin altını çizilmiştir. Benzer şekilde Ivanov ve Stavrinoudis (2018), 2015 mülteci krizinin otel endüstrisi üzerindeki etkilerini incelemek amacıyla Yunanistan'da 96 otel yöneticisi üzerinde bir araştırma gerçekleştirmiştir. Araştırma sonucunda mülteci krizinin otel endüstrisi üzerinde önemli ölçüde olumsuz etkisi olduğunu ve operasyonel istatistiklerinin de önemli ölçüde bozulduğu görülmüştür. Bununla beraber destinasyonun ve konaklama tesislerinin imajının da zarar gördügüünü ortaya konulmuştur.

Endrich ve Michel (2018), mülteciler ve turizm arasındaki ilişkiyi incelemek amacıyla bir araştırma gerçekleştirmiştir. Araştırma sonucunda mülteci karşıtllı̆̆ amacıyla yapılan gösterilerin turistlerin gelişimini olumsuz etkilediği görülmüştür. Benzer bir araştırmada Aratimur ve Akgündüz (2018), Türkiye'yi bir destinasyon olarak seçmek isteyen yabancı turistlerin, ülkedeki sığınmacıların varlığından nasıl etkilendiklerini belirlemek amacıyla 412 kişi üzerinde bir araştırma gerçekleştirmiştir. Araştırma sonucunda bireylerin destinasyon tercihlerinde mültecilerin varlığından rahatsız oldukları görülmüştür. Diğer taraftan Melotti (2018), Akdeniz'deki turizm ve mülteci krizi üzerine Lampedusa'da bir alan araştırması gerçekleştirmiştir. Araştırma sonucunda Lampedusa adasının mültecilerin Avrupa'ya geçme güzergahı üzerinde bulunduğu ve binlerce mültecinin bu yolda ölümle karşılaştığını belirtmektedir. Bu olayların medyada yer almasından sonra adayı küresel bir simgeye dönüştüğü ve bölgeye turist gelmesinin sağladığ (2011) azınlık nüfuslarının sunduğu cazibe merkezlerinin çeşitliliği ve benzersizliğini teşvik ederek turizm destinasyonlarının çekiciliğini incelemek amacıyla 250 kişi üzerinde bir araştırma gerçekleştirmiştir. Araştırma sonucunda etnik azınlıkların gelenek ve görenekleri, dilleri ve mimari üsluplarıyla turistler için kesinlikle katma değer sağlayabileceği görülmüştür.

Turizm sektörü, son yıllarda ekonomik etkinliğini artırmaya devam etmesine karşın mülteci sorunu diğer tüm sektörlerde olduğu gibi turizm sektöründe de sorun olarak karşımıza çımmaktadır. Başka bir ifade ile dünyanın her köşesindeki turizm destinasyonları, mülteci sorunu ile karşı karşıyadır. Ancak Suriye ve Ortadoğu ile komşu olmasından dolayı mülteci sorunu en fazla Türkiye'nin gündeminde yer almaktadır. Özellikle Suriye ile sınır komşuluğu bulunan bu illerde mülteci sorunu en büyük sorun olarak karşımıza çıkmaktadır. Suriye ile sınır komşuluğu bulunan ve aynı zamanda da gastronomi alanında UNESCO "Yaratıcı Şehirler Ağına" girmeyi başaran Gaziantep şehrinde de mülteciler önemli bir gündem oluşturmaktadırlar. Tüm dünyanın 
en büyük sorunu olarak karşımıza çıkan mültecilerin turizm destinasyonlarına etkisinin olup olmadığının daha önce araştırılmamış olması bu araştırmanın problemini oluşturmaktadır. Dolayısıyla bu araştırma sonucunda destinasyonlarda mültecilere yönelik algılara ilişkin ampirik bulgular ortaya konması ve sektör yöneticileri ile araştırmacılara çeşitli öneriler sunulması nedeniyle önemlidir.

\section{ARAŞTIRMANIN YÖNTEMI}

Araştırmanın bu bölümünde, araştırmanın yöntemi hakkında detaylı bilgilere yer verilmiştir. Bu kapsamda öncelikle araştırmanın amacı ve teorik modeli ortaya konulmaktadır. Daha sonra anket formunun içeriği ve örneklem grubunun seçimi açıklanmıştır.

\section{Araştırmanın Amacı ve Teorik Modeli}

Göç ve turizmin karşılıklı bağımlılı̆̆ı, alan yazında az ilgi gören konulardandır (Seetaram, 2012). Mülteci akımlarının turizm üzerindeki etkileri üzerine yapılan araştırmalar neredeyse mevcut değildir. Başka bir ifade ile az sayıda destinasyon mülteci sorunu ile baş etmelerine yardımcı olacak stratejik planlara sahiptir. Çünkü ilgili alan yazında bu konuyla ilgili sınırlı araştırmalar yer almaktadır. Bu kapsamda gerçekleştirilen bu araştırmanın amacı, destinasyonlarda mültecilere yönelik algıların destinasyona yönelik kişilik, imaj, tutum, memnuniyet ve davranışsal niyete etkisinin belirlenmesidir. Başka bir ifade ile mültecilerin destinasyon yönetiminde bir sorun olup olmadığı bu araştırmayla ortaya konacaktır. Bununla birlikte mülteciler ile karşı karşıya kalan destinasyonlarda mülteci sorununun çözümü için genel bir model ortaya konması da yine bu araştırmanın amacını oluşturmaktadır.

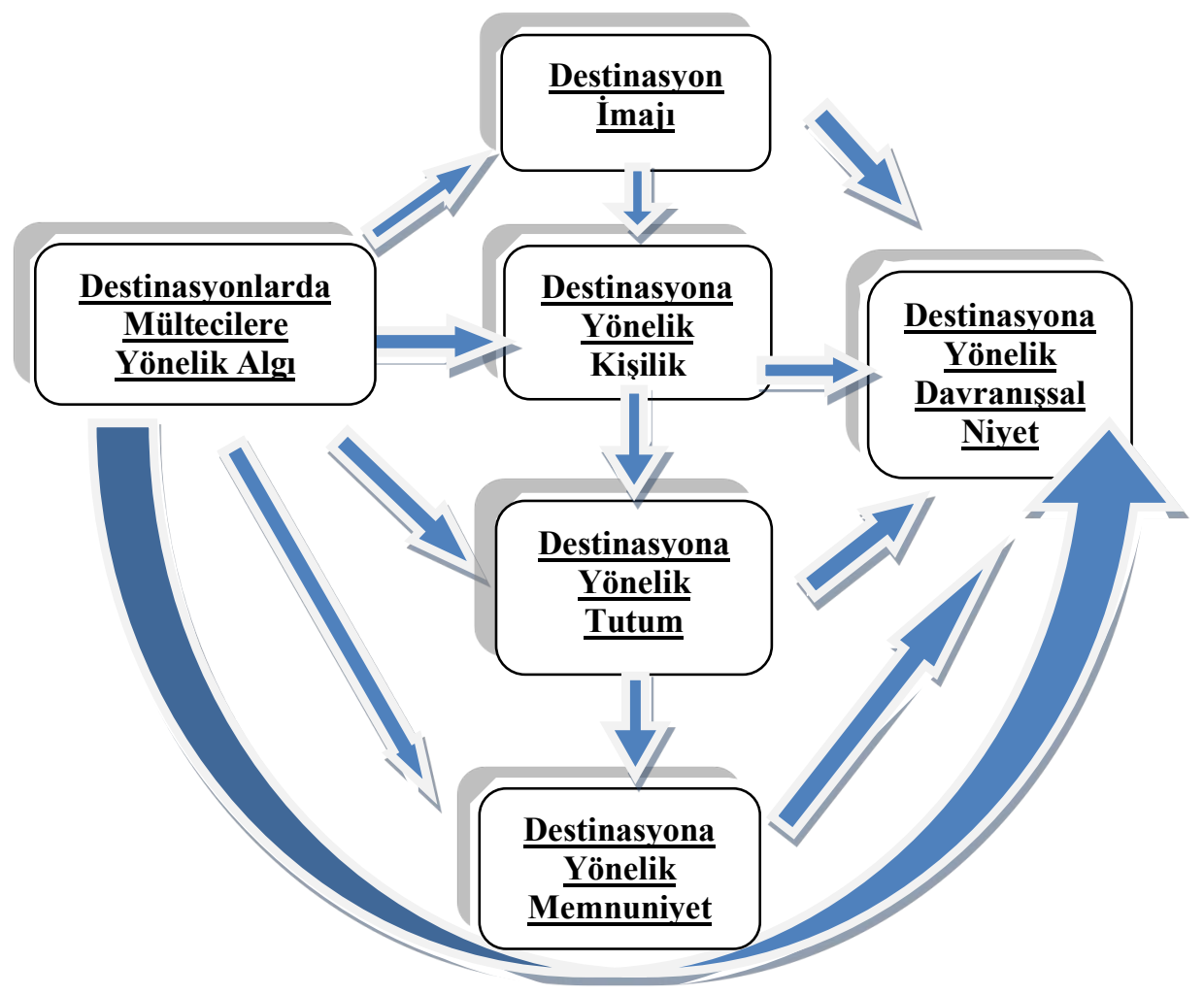

Şekil 1. Araştırmanın Teorik Modeli 
Destinasyona yönelik imaj memnuniyet, kişilik, tutum ve davranışsal niyet değişkenlerine ilişkin birçok araştırma gerçekleştirilmiştir. Çelik, Öztürk ve Coşkun (2019) destinasyon kişiliğinin davranışsal niyet üzerinde etkisi olduğunu ortaya koymuştur. Hallab ve Kim, (2011) destinasyon imajı ile davranışsal niyet arasında bir ilişki olduğunu yapmış oldukları araştırmalarında ortaya koymuşlardır. Ancak gerçekleştirilen bu araştırmaların hiçbirinde mültecilere yönelik alg1 modele dâhil edilmemiştir. Tüm bu bilgiler ışığında araştırmanın teorik modeli oluşturulmuş ve modele mültecilere yönelik algı değişkeni dâhil edilmiştir. Destinasyonlarda mültecilere yönelik algıların destinasyona yönelik kişilik, imaj, tutum, memnuniyet ve davranışsal niyete etkisini belirleyerek mülteciler ile karşı karşıya kalan destinasyonlarda mülteci sorununun çözümü için model geliştirilmesi amaçlanmıştır. Araştırmanın amacı kapsamında oluşturulan model Şekil 1'de gösterilmiştir.

\section{Anket Formunun İçeriği ve Örneklem Grubunun Seçimi}

Destinasyonlarda mültecilere yönelik algıların destinasyona yönelik kişilik, imaj, tutum, memnuniyet ve davranışsal niyete etkisinin belirlenmesi amacıyla yapılan araştırmada veri toplama sürecinde anket yöntemi kullanılmıştır. Araştırmada elde edilen veriler kolayda örnekleme yöntemi ile toplanmıştır. Anket soruları alan yazın taranarak (Akkılıç ve Varol, 2015; De Nisco, Mainolfi, Marino ve Napolitano, 2015; Pappas ve Papatheodorou, 2017; Souiden, Ladhari ve Chiadmi, 2017; Aratimur ve Akgündüz, 2018) ve bu alanda uzman öğretim üyelerinin görüşleri de dikkate alınarak hazırlanmıştır. Birinci bölümde mültecilerin turizme etkisini belirlemeye yönelik 39 soru ikinci bölümde katılımcıların demografik ve tanıtıcı özelliklerini belirlemeye yönelik dokuz adet soru bulunmaktadır.

Bu araştırmanın örneklemini ise Gaziantep ilini 2019 yılının Mart-Nisan aylarında ziyaret eden ve kolayda örneklem yöntemi ile ulaşılan 503 yerli turist oluşturmaktadır. Örneklem seçiminde turistlerin en yoğun tercih ettiği bölgeler olan "Gaziantep Kalesi ve civarı, Zeugma Mozaik Müzesi, Gaziantep Hayvanat Bahçesi" tercih edilmiştir. Bu şekilde örneklemin adil bir şekilde dağılması amaçlanmıştır.

\section{BULGULAR}

Bu bölümde araştırmada elde edilen bulgular tablolar halinde gösterilmiş ve yorumlanmıştır. Buna göre ilk başlıkta doğrulayıcı faktör analizine yönelik bulgular, ikinci bölümde katılımcıların tanıtıcı özellikleri ve son bölümde ise araştırma modelinde yer alan değişkenler ile ilgili yol analizi bulguları yer almaktadır.

\section{Doğrulayıcı Faktör Analizine Yönelik Bulgular}

Doğrulayıcı faktör analizinde en önemli nokta ölçüm modelinin belirlenmesidir (Çokluk, Şekercioğlu ve Büyüköztürk, 2010: 265-266). DFA'a uyum iyiliği değerlerine bakılarak en uygun modelin hangisi olduğuna karar verilmesi gerekmektedir. Model uyumunun test edilmesi için çeşitli istatistikler bulunmaktadır. En çok kullanılan istatistikler; Ki-kare istatistiği, GFI, CFI ve RMSEA sayılabilir. Ki-kare istatistiği, $\chi 2 / \mathrm{df}<2$ ise mükemmel uyumu ve $\chi 2 / \mathrm{df}<3$ ise kabul edilebilir uyumu göstermektedir. Uyum iyiliği indeksi (GFI) ve Karşılaştırmalı uyum indeksi (CFI); 0,90 ve daha üstü değerler kabul edilebilir uyumu göstermektedir. Yaklaşık hataların ortalama karekökü (RMSEA) 0 ile 1 değerleri arasında değişmektedir. Sıfıra (0) yakın değerler vermesi beklenmektedir (Kelloway, 1998; Byrne, 2016). Şekil 2'de destinasyona yönelik imaj ölçeğinin doğrulayıcı faktör analizi sonucunda elde edilen bulgular gösterilmiştir. 


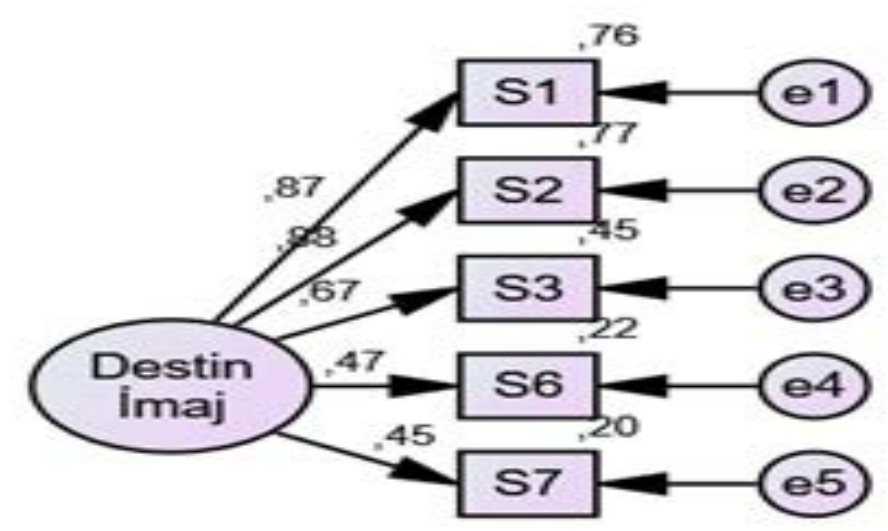

Şekil 2. Destinasyona Yönelik İmaj Ölçeğinin Doğrulayıcı Faktör Analizine İlişkin Bulgular

DFA sonucu faktör yüklerinin 0,45 ile 0,87 arasında olduğu görülmüştür. Bununla beraber destinasyona yönelik imaj ölçeği hesaplanan uyum iyiliği değerleri Tablo 1'de gösterilmiştir.

Tablo 1. Destinasyona Yönelik İmaj Ölçeği Hesaplanan Uyum İyiliği Değerleri

\begin{tabular}{lllllll}
\hline Değişken & CMIN/ & GFI & AGFI & CFI & TLI & $\begin{array}{l}\text { RMSEA } \\
\text { DF } \leq 5\end{array}$ \\
& $\geq .85$ & $\geq .80$ & $\geq .90$ & $\geq .90$ & $\leq .08$ \\
\hline $\begin{array}{l}\text { Destinasyona } \\
\text { Yönelik İmaj }\end{array}$ & 2.36 & 0.991 & 0.972 & 0.992 & 0.985 & 0.052 \\
\hline
\end{tabular}

Doğrulayıcı faktör analizi sonucunda, elde edilen destinasyona yönelik imaj ölçeği hesaplanan uyum iyiliği indekslerine bakıldığında; araştırma kapsamında toplanan verilerin uygun uyum iyiliği değerlerine sahip olduğu sonucuna varılmıştır. Bu noktada, ölçek maddelerinin boyutlar tarafından doğru açıklandığı ve ölçeğin yapı geçerliliğinin sağlandığı görülmüştür. Şekil 3'de destinasyona yönelik kişilik ölçeğinin doğrulayıcı faktör analizi sonucunda elde edilen bulgular gösterilmiştir.

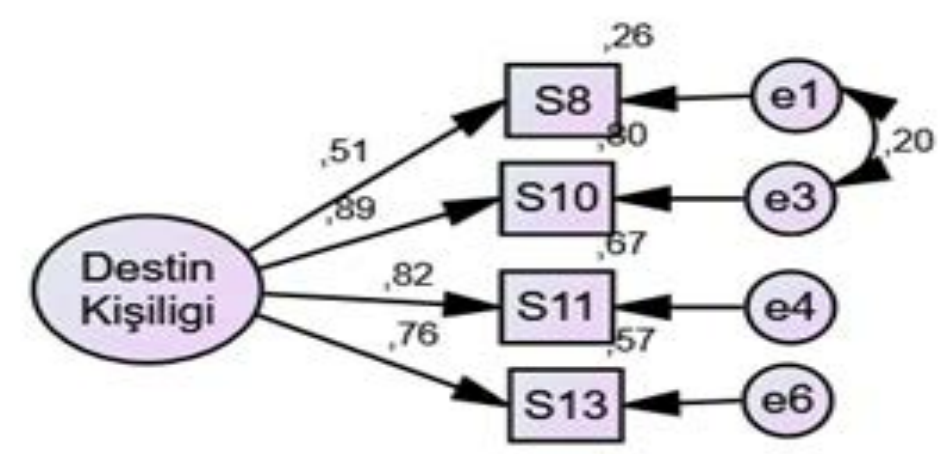

Şekil 3. Destinasyona Yönelik Kişilik Ölçeğinin Doğrulayıcı Faktör Analizine İlişkin Bulgular 
DFA sonucu faktör yüklerinin 0,51 ile 0,89 arasında olduğu görülmüştür. Bununla beraber destinasyona yönelik kişilik ölçeği hesaplanan uyum iyiliği değerleri Tablo 2'da gösterilmiştir.

Tablo 2. Destinasyona Yönelik Kişilik Ölçeği Hesaplanan Uyum İyiliği Değerleri

\begin{tabular}{lllllll}
\hline Değişken & CMIN/ & GFI & AGFI & CFI & TLI & RMSEA \\
& DF $\leq 5$ & $\geq .85$ & $\geq .80$ & $\geq .90$ & $\geq .90$ & $\leq .08$ \\
\hline Destinasyona & 0,346 & 1,000 & 0.997 & 1,000 & 1,004 & 0.000 \\
Yönelik Kişilik & & & & & & \\
\hline
\end{tabular}

Doğrulayıcı faktör analizi sonucunda, elde edilen destinasyona yönelik kişilik ölçeği hesaplanan uyum iyiliği indekslerine bakıldığında; araştırma kapsamında toplanan verilerin uygun uyum iyiliği değerlerine sahip olduğu sonucuna varılmıştır. Bu noktada, ölçek maddelerinin boyutlar tarafından doğru açıklandığı ve ölçeğin yapı geçerliliğinin sağlandığı görülmüştür. Şekil 4'da destinasyona yönelik memnuniyet ölçeğinin doğrulayıcı faktör analizi sonucunda elde edilen bulgular gösterilmiştir.

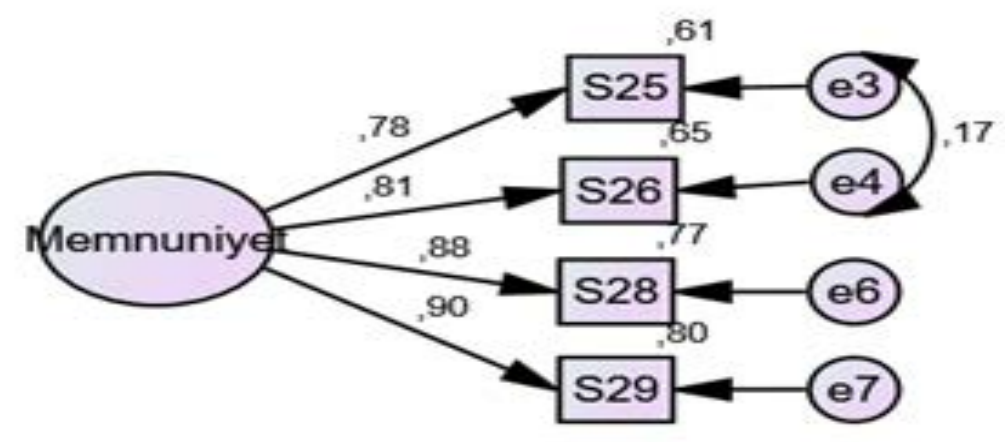

Şekil 4. Destinasyona Yönelik Memnuniyet Ölçeğinin Doğrulayıcı Faktör Analizine İlişkin Bulgular

DFA sonucu faktör yüklerinin 0,78 ile 0,90 arasında olduğu görülmüştür. Bununla beraber destinasyona yönelik memnuniyet ölçeği hesaplanan uyum iyiliği değerleri Tablo 11'da gösterilmiştir.

Tablo 3. Destinasyon Yönelik Memnuniyet Ölçeği Hesaplanan Uyum İyiliği Değerleri

\begin{tabular}{lllllll}
\hline Değişken & CMIN/ & GFI & AGFI & CFI & TLI & $\begin{array}{l}\text { RMSEA } \\
\text { DF } \leq 5\end{array}$ \\
& $\geq .85$ & $\geq .80$ & $\geq .90$ & $\geq .90$ & $\leq .08$ \\
\hline $\begin{array}{l}\text { Destinasyona } \\
\begin{array}{l}\text { Yönelik } \\
\text { Memnuniyet }\end{array}\end{array}$ & 0,761 & 0,999 & 0.992 & 1,000 & 1,001 & 0.000 \\
\hline
\end{tabular}

Doğrulayıcı faktör analizi sonucunda, elde edilen destinasyona yönelik memnuniyet ölçeği hesaplanan uyum iyiliği indekslerine bakıldığında; araştırma kapsamında toplanan verilerin uygun uyum iyiliği değerlerine sahip olduğu sonucuna varılmıştır. Bu noktada, ölçek 
maddelerinin boyutlar tarafından doğru açıklandığı ve ölçeğin yapı geçerliliğinin sağlandığ1 görülmüştür. Şekil 5'da destinasyona yönelik tutum ölçeğinin doğrulayıcı faktör analizi sonucunda elde edilen bulgular gösterilmiştir.

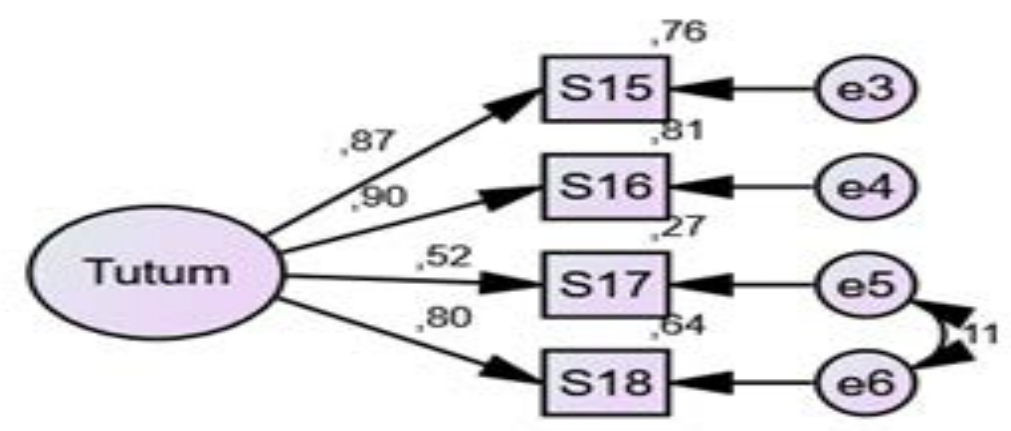

Şekil 5. Destinasyona Yönelik Tutum Ölçeğinin Doğrulayıcı Faktör Analizine İlişkin Model

DFA sonucu faktör yüklerinin 0,52 ile 0,90 arasında olduğu görülmüştür. Bununla beraber destinasyona yönelik tutum ölçeği hesaplanan uyum iyiliği değerleri Tablo 4'de gösterilmiştir.

Tablo 4. Destinasyon Yönelik Tutum Ölçeği Hesaplanan Uyum İyiliği Değerleri

\begin{tabular}{lllllll}
\hline Değişken & CMIN/ & GFI & AGFI & CFI & TLI & RMSEA \\
& DF $\leq 5$ & $\geq .85$ & $\geq .80$ & $\geq .90$ & $\geq .90$ & $\leq .08$ \\
\hline Destinasyona & 0,034 & 1,000 & 1,000 & 1,000 & 1,006 & 0.000 \\
Yönelik Tutum & & & & & & \\
\hline
\end{tabular}

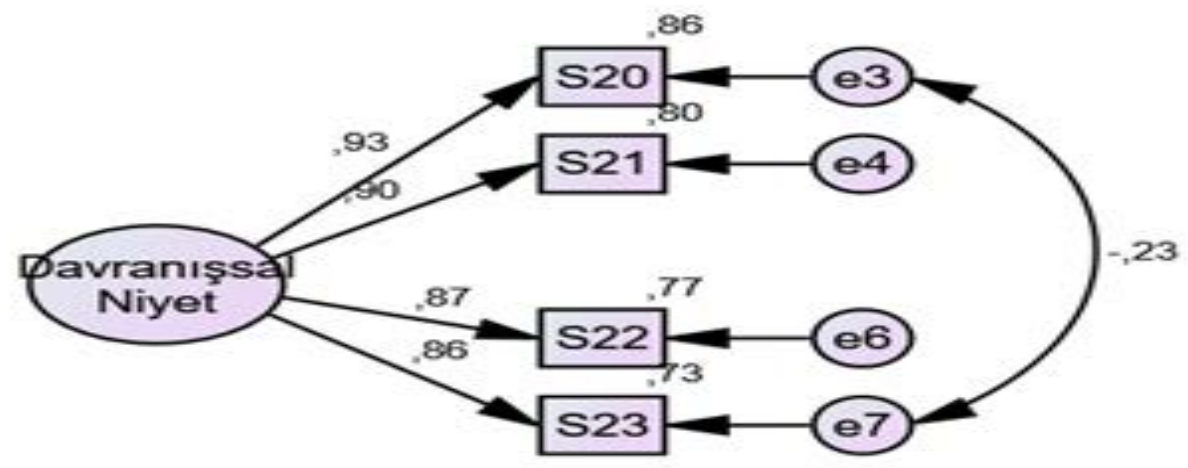

Şekil 6. Destinasyona Yönelik Davranışsal Niyet Ölçeğinin Doğrulayıcı Faktör Analizine İlişkin Bulgular

Doğrulayıcı faktör analizi sonucunda, elde edilen destinasyona yönelik tutum ölçeği hesaplanan uyum iyiliği indekslerine bakıldığında; araştırma kapsamında toplanan verilerin uygun uyum iyiliği değerlerine sahip olduğu sonucuna varılmıştır. Bu noktada, ölçek maddelerinin boyutlar tarafından doğru açıklandığı ve ölçeğin yapı geçerliliğinin sağlandığı görülmüştür. Şekil $6^{\prime}$ de 
destinasyona yönelik davranışsal niyet ölçeğinin doğrulayıcı faktör analizi sonucunda elde edilen bulguları gösterilmiştir.

DFA sonucu faktör yüklerinin 0,86 ile 0,93 arasında olduğu görülmüştür. Bununla beraber destinasyona yönelik davranışsal niyet ölçeği hesaplanan uyum iyiliği değerleri Tablo 5'de gösterilmiştir.

Tablo 5. Destinasyon Davranışsal Niyet Ölçeğine Yönelik Hesaplanan Uyum İyiliği Değerleri

\begin{tabular}{lllllll}
\hline Değişken & CMIN/ & GFI & AGFI & CFI & TLI & $\begin{array}{l}\text { RMSEA } \\
\end{array}$ \\
& DF $\leq 5$ & $\geq .85$ & $\geq .80$ & $\geq .90$ & $\geq .90$ & $\leq .08$ \\
\hline $\begin{array}{l}\text { Destinasyona } \\
\text { Yönelik Davranişsal }\end{array}$ & 0,265 & 1,000 & 0,997 & 1,000 & 1,003 & 0.000 \\
Niyet & & & & & & \\
\hline
\end{tabular}

Doğrulayıcı faktör analizi sonucunda, elde edilen destinasyona yönelik davranışsal niyet ölçeği hesaplanan uyum iyiliği indekslerine bakıldığında; araştırma kapsamında toplanan verilerin uygun uyum iyiliği değerlerine sahip olduğu sonucuna varılmıştır. Bu noktada, ölçek maddelerinin boyutlar tarafından doğru açıklandığı ve ölçeğin yapı geçerliliğinin sağlandığı görülmüştür. Şekil 7'de destinasyonlarda mültecilere yönelik algı ölçeğinin doğrulayıcı faktör analizi sonucunda elde edilen bulguları gösterilmiştir.

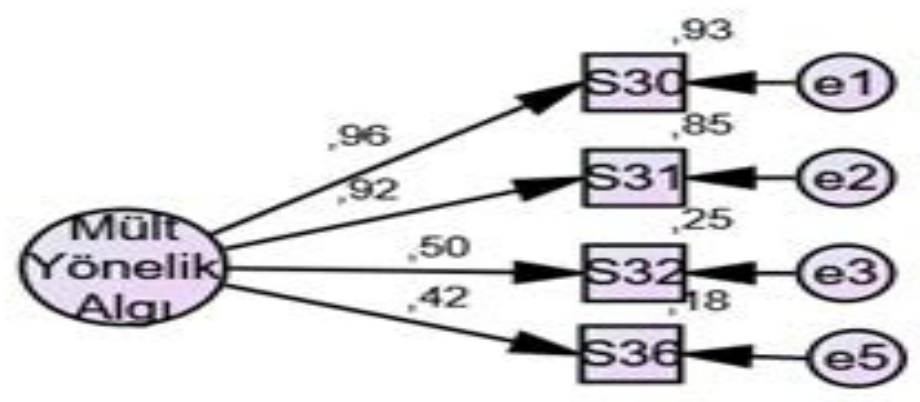

Şekil 7. Mültecilere Yönelik Alg1 Ölçeğinin Doğrulayıcı Faktör Analizine İlişkin Bulgular

DFA sonucu faktör yüklerinin 0,42 ile 0,96 arasında olduğu görülmüştür. Bununla beraber destinasyona yönelik destinasyonlarda mültecilere yönelik algı ölçeği hesaplanan uyum iyiliği değerleri Tablo 6'da gösterilmiştir.

Tablo 6. Destinasyonlarda Mültecilere Yönelik Alg1 Ölçeğine Yönelik Hesaplanan Uyum İyiliği Değerleri

\begin{tabular}{lllllll}
\hline Değişken & CMIN/ & GFI & AGFI & CFI & TLI & $\begin{array}{l}\text { RMSEA } \\
\text { DF } \leq 5\end{array}$ \\
& $\geq .85$ & $\geq .80$ & $\geq .90$ & $\geq .90$ & $\leq .08$ \\
\hline $\begin{array}{l}\text { Destinasyonlarda } \\
\text { Mültecilere Yönelik }\end{array}$ & 2,372 & 0,995 & 0,977 & 0,997 & 0,992 & 0.052 \\
Alg1 & & & & & & \\
\hline
\end{tabular}


Doğrulayıcı faktör analizi sonucunda, elde edilen destinasyonlarda mültecilere yönelik alg1 ölçeği hesaplanan uyum iyiliği indekslerine bakıldığında; araştırma kapsamında toplanan verilerin uygun uyum iyiliği değerlerine sahip olduğu sonucuna varılmıştır. Bu noktada, ölçek maddelerinin boyutlar tarafından doğru açıklandığı ve ölçeğin yapı geçerliliğinin sağlandığı görülmüştür.

\section{Katılımcıların Tanıtıcı Özellikleri ve Gaziantep Ziyaretine İlişkin Bulgular}

Bu başlıkta, katılımcıların tanıtıcı özellikleri Tablo 7'de ve Gaziantep ziyaretine ilişkin bulgular ise Tablo 8' de gösterilmiştir.

Tablo 7. Araştırmaya Katılanların Kişisel Bilgilerine İlişkin Bulgular

\begin{tabular}{clccc}
\hline Değişkenler & & Gruplar & $\mathbf{n}$ & $\mathbf{\%}$ \\
\hline \multirow{2}{*}{ Cinsiyet } & Kadın & 222 & 44,1 \\
& Erkek & 281 & 55,9 \\
\hline \multirow{2}{*}{ Yaş } & $18-29$ & 185 & 36,8 \\
& $30-39$ & 183 & 36,4 \\
& $40-49$ & 76 & 15,1 \\
& 50 ve üzeri & 59 & 11,7 \\
\hline Toplam & & $\mathbf{5 0 3}$ & $\mathbf{1 0 0 , 0}$ \\
\hline \multirow{2}{*}{ Medeni Durum } & Evli & 286 & 56,9 \\
& Bekâr & 217 & 43,1 \\
\hline \multirow{3}{*}{ Eğitim Durumu } & İlkokul ve Ortaokul & 62 & 12,3 \\
& Lise & 76 & 15,1 \\
& Ön lisans & 73 & 14,5 \\
& Lisans & 212 & 42,1 \\
& Lisansüstü & 80 & 15,9 \\
\hline Toplam & & $\mathbf{5 0 3}$ & $\mathbf{1 0 0 , 0}$ \\
\hline \multirow{2}{*}{ Aylık Gelir Durumu } & 2001-3500 & 107 & 21,3 \\
(TL) & 3501-5000 & 102 & 20,3 \\
& 5001 ve üzeri & 137 & 27,2 \\
\hline Toplam & & 157 & 31,2 \\
\hline
\end{tabular}

Araştırmaya katılan katılımcıların cinsiyete göre dağılımları incelendiğinde, katılımcıların yüzde 44,1'inin kadın, yüzde 55,9' 'unun erkek olduğu görülmektedir. Katılımclların yüzde 36,8'inin 1829 yaş aralığında, yüzde 36,4'ünün 30-39 yaş aralığında, yüzde 15,1'inin 40-49 yaş aralığında ve yüzde 11,7'sinin ise 50 yaş ve üzeri olduğu görülmüştür.

Katılımcların medeni duruma göre dağılımları incelendiğinde, katılımcıların yüzde 56,9'unun evli ve yüzde 43,1'inin ise bekâr olduğu görülmektedir. Araştırmaya katılan katılımcıların eğitim durumlarına göre dağılımları incelendiğinde, katılımclların yüzde 12,3'ünün ilkokul ve ortaokul, yüzde 15,1'inin lise, yüzde 14,5'inin ön lisans, yüzde 42,1'inin lisans ve yüzde 15,9'unun ise lisansüstü eğitim aldığı görülmüştür.

Katılımcların aylık gelirlerine göre dağılımları incelendiğinde, katılımcıların yüzde 21,3'ünün $2000 \mathrm{TL}$ ve altı, yüzde 20,3'ünün 2001-3500 TL aralığında, yüzde 27,2'sinin 3501-5000 TL aralığında ve yüzde $31,2^{\prime}$ sinin ise 5001 TL ve üzeri gelire sahip olduğu görülmüştür. 
Tablo 1. Araştırmaya Katılanların Gaziantep Ziyaretine İlişkin Bulgular

\begin{tabular}{clcc}
\hline Değişkenler & Gruplar & $\mathbf{n}$ & $\mathbf{\%}$ \\
\hline & Tatil & 272 & 54,1 \\
& Gastronomi & 31 & 6,2 \\
Gaziantep'e Geliş & İş & 66 & 13,1 \\
Amacı & Kültür ve tarih & 72 & 14,3 \\
& Alışveriş & 15 & 3,0 \\
& Diğer & 47 & 9,3 \\
\hline Toplam & & $\mathbf{5 0 3}$ & $\mathbf{1 0 0 , 0}$ \\
\hline \multirow{2}{*}{ Gaziantep'te } & 1-2 gün & 320 & 63,6 \\
Konaklama Süresi & 3-4 gün & 105 & 20,9 \\
& 5 ve daha fazla & 78 & 15,5 \\
\hline Toplam & & $\mathbf{5 0 3}$ & $\mathbf{1 0 0 , 0}$ \\
\hline \multirow{2}{*}{ Gaziantep'i Kim ile } & Kendim & 95 & 18,9 \\
Ziyaret Ettiniz? & Arkadaşlarımla & 186 & 37,0 \\
& Ailemle / Çocuklarımla & 105 & 20,9 \\
& Ailemle / Çocuksuz & 84 & 16,7 \\
& Tur ile & 33 & 6,6 \\
\hline Toplam & & $\mathbf{5 0 3}$ & $\mathbf{1 0 0 , 0}$ \\
\hline
\end{tabular}

Araştırmaya katılan katılımcıların Gaziantep'e geliş amaçlarına göre dağılımları incelendiğinde, katılımclların yüzde 54,1'inin tatil, yüzde 6,2'sinin gastronomi, yüzde 13,1'inin iş, yüzde 14,3'ünün kültür ve tarih, yüzde 3'ünün alışveriş ve yüzde 9,3'ünün diğer nedenlerle Gaziantep'i ziyaret ettiği görülmektedir. Katılımciların yüzde 63,6'sının 1-2 gün, yüzde 20,9'unun 3-4 gün ve yüzde 15,5'inin ise 5 gün ve daha fazla konaklama yaptığı görülmüştür.

Katılımcıların Gaziantep'i kiminle ziyaret ettiklerine yönelik dağılım incelendiğinde, katılımcların yüzde 18,9'unun tek başına, yüzde $37^{\prime}$ sinin arkadaşlarıyla, yüzde 20,9'unun ailesi/çocuklarıyla, yüzde $16,7^{\prime} \operatorname{sinin}$ ailesiyle/çocuksuz ve yüzde $6,6^{\prime}$ sının ise tur ile seyahat ettikleri görülmüştür.

\section{Araştırma Modelinde Yer Alan Değişkenler ile İlgili Yol Analizi Bulguları}

Araştırmanın bu bölümünde, destinasyonlarda mültecilere yönelik algıların destinasyona yönelik kişilik, imaj, tutum, memnuniyet ve davranışsal niyete etkisinin belirlenmesi için yapısal eşitlik modellemesi kurulmuş ve model üzerinden analizler gerçekleştirilmiştir. Kurulan yapısal eşitlik modeli Şekil 8'de, yapısal modelin uyum iyiliği değerleri Tablo 9'da ve yapısal modelin regresyon ağırlığı değerleri ise Tablo 10'de gösterilmiştir.

Tablo 9'da modelin uyum indeksleri incelendiğinde; GFI (Goodness of fit index) değerinin 1,000, AGFI (Adjusted goodness of fit index) değerinin 0,995, CFI (Comperative fit index-Karşılaştırmalı uyum indeksi) değerinin 1,000, TLI (Tucher- Lewis indeksi) değerinin 1,000, CMIN/DF değerinin 0,354 , ve RMSEA (Root mean square error of approximation-Kök ortalama kare yaklaşım hatası) değerinin de 0,000 olduğu tespit edilmiştir. Elde edilen bu değerler mükemmele yakın değerler verdiği için oluşturulan yapısal eşitlik modelinin kabul edilebilir olduğu görülmüştür. Dolayısıyla, bu durum modelin mükemmel iyi uyum gösterdiğini belirtmektedir. 


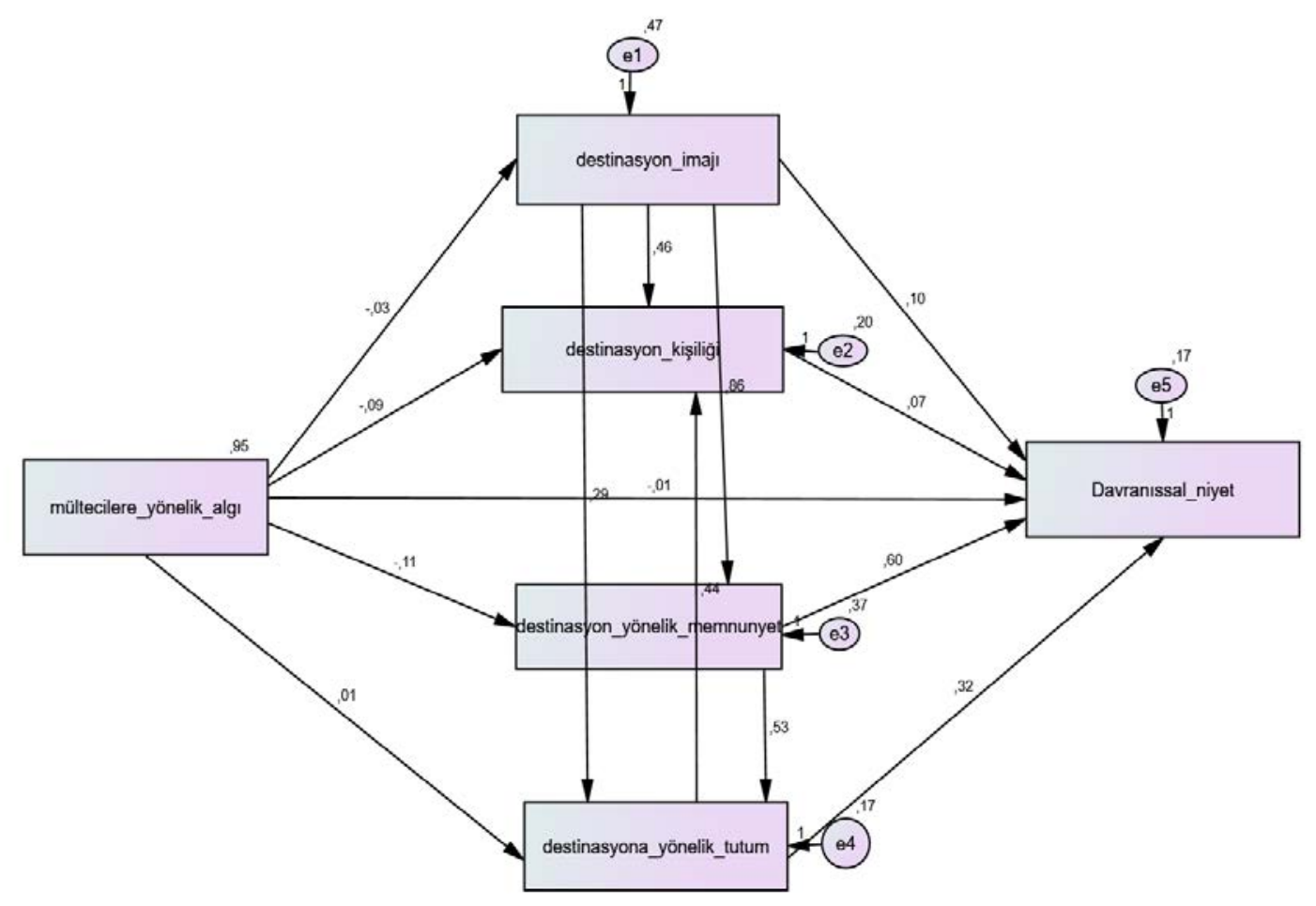

Şekil 8. Yapısal Eşitlik Modeli

Tablo 2. Yapısal Eşitlik Modeli Uyum İyiliği Değerleri ve hesaplanan değerler (İlhan ve Çetin, 2014:31)

\begin{tabular}{lccc}
\hline $\begin{array}{c}\text { Uyum } \\
\text { Indeksleri }\end{array}$ & $\begin{array}{c}\text { Mükemmel Uyum } \\
\text { İndeksleri }\end{array}$ & $\begin{array}{c}\text { Kabul Edilebilir Uyum } \\
\text { İndeksleri }\end{array}$ & $\begin{array}{c}\text { Hesaplanan } \\
\text { değerler }\end{array}$ \\
\hline CMIN/DF & $0 \leq \mathrm{x}^{2} / \mathrm{sd} \leq 2$ & $2 \leq \mathrm{x}^{2} / \mathrm{sd} \leq 3$ & $\mathbf{0 , 3 5 4}$ \\
\hline RMSEA &, $00 \leq \mathrm{RMSEA} \leq, 05$ &, $05 \leq \mathrm{RMSEA} \leq, 08$ & $\mathbf{0 , 0 0 0}$ \\
\hline GFI & $, 95 \leq \mathrm{GFI} \leq 1,00$ &, $90 \leq \mathrm{GFI} \leq, 95$ & $\mathbf{1 , 0 0 0}$ \\
\hline AGFI & $, 90 \leq \mathrm{AGFI} \leq 1,00$ &, $85 \leq \mathrm{AGFI} \leq, 90$ & $\mathbf{0 , 9 9 5}$ \\
\hline CFI & $, 95 \leq \mathrm{CFI} \leq 1,00$ &, $90 \leq \mathrm{CFI} \leq, 95$ & $\mathbf{1 , 0 0 0}$ \\
\hline TLI & $, 95 \leq \mathrm{TLI} \leq 1,00$ & $, 90 \leq \mathrm{TLI} \leq 1,00$ & $\mathbf{1 , 0 0 0}$ \\
\hline
\end{tabular}

Tablo 9'da görüldüğü gibi bütün değerlerinin mükemmel sınırların üzerinde olduğu görülmüştür. Yapısal model ile analiz edilen regresyon ağırlı̆ 1 sonuçları ise Tablo 10'da gösterilmiştir. 
Tablo 3. Yapısal Model Regresyon Ağırlıkları

\begin{tabular}{|c|c|c|c|c|c|c|c|}
\hline \multicolumn{3}{|c|}{ Test Edilen Yol } & $\begin{array}{l}\text { Standardize } \\
\text { Edilmemiş } \\
\text { Beta }\end{array}$ & $\begin{array}{l}\text { Standar } \\
\text { t Beta }\end{array}$ & $\begin{array}{l}\text { Standar } \\
\text { t Hata }\end{array}$ & $T$ & p \\
\hline $\begin{array}{l}\text { Destinasyona yönelik } \\
\text { imaj }\end{array}$ & $\begin{array}{l}<- \\
--\end{array}$ & $\begin{array}{l}\text { Mültecilere yönelik } \\
\text { alg1 }\end{array}$ & $-0,028$ & $-0,04$ & 0,031 & $\begin{array}{l}0,9 \\
07\end{array}$ & $\begin{array}{l}0,3 \\
64\end{array}$ \\
\hline $\begin{array}{l}\text { Destinasyona } \\
\text { yönelik memnuniyet }\end{array}$ & \begin{tabular}{|l}
$<-$ \\
-- \\
\end{tabular} & $\begin{array}{l}\text { Destinasyona } \\
\text { yönelik imaj }\end{array}$ & 0,856 & 0,688 & 0,04 & $\begin{array}{l}21, \\
646 \\
\end{array}$ & $* * *$ \\
\hline $\begin{array}{l}\text { Destinasyona } \\
\text { yönelik memnuniyet }\end{array}$ & $\begin{array}{l}<- \\
--\end{array}$ & $\begin{array}{l}\text { Mültecilere yönelik } \\
\text { alg1 }\end{array}$ & $-0,106$ & $-0,121$ & 0,028 & $\begin{array}{l}- \\
3,8 \\
24\end{array}$ & $* * *$ \\
\hline $\begin{array}{l}\text { Destinasyona yönelik } \\
\text { tutum }\end{array}$ & $\begin{array}{l}<- \\
-- \\
\end{array}$ & $\begin{array}{l}\text { Mültecilere yönelik } \\
\text { alg1 }\end{array}$ & 0,015 & 0,019 & 0,019 & $\begin{array}{l}0,7 \\
69 \\
\end{array}$ & $\begin{array}{l}0,4 \\
42 \\
\end{array}$ \\
\hline $\begin{array}{l}\text { Destinasyona } \\
\text { yönelik tutum }\end{array}$ & $\begin{array}{l}<- \\
-- \\
\end{array}$ & $\begin{array}{l}\text { Destinasyona } \\
\text { yönelik imaj }\end{array}$ & 0,294 & 0,275 & 0,037 & \begin{tabular}{|l|}
7,9 \\
91 \\
\end{tabular} & $* * *$ \\
\hline $\begin{array}{l}\text { Destinasyona } \\
\text { yönelik tutum }\end{array}$ & $\begin{array}{l}<- \\
--\end{array}$ & $\begin{array}{l}\text { Destinasyona } \\
\text { yönelik memnuniyet }\end{array}$ & 0,533 & 0,62 & 0,03 & $\begin{array}{l}17 \\
832 \\
\end{array}$ & $* * *$ \\
\hline $\begin{array}{l}\text { Destinasyona } \\
\text { yönelik kişilik }\end{array}$ & $\begin{array}{l}<- \\
--\end{array}$ & $\begin{array}{l}\text { Destinasyona } \\
\text { yönelik tutum }\end{array}$ & 0,439 & 0,431 & 0,039 & $\begin{array}{l}11, \\
375\end{array}$ & $* * *$ \\
\hline $\begin{array}{l}\text { Destinasyona } \\
\text { yönelik kişilik }\end{array}$ & $\begin{array}{l}<- \\
--\end{array}$ & $\begin{array}{l}\text { Destinasyona } \\
\text { yönelik imaj }\end{array}$ & 0,455 & 0,418 & 0,041 & $\begin{array}{l}11, \\
049\end{array}$ & $* * *$ \\
\hline $\begin{array}{l}\text { Destinasyona } \\
\text { yönelik kişilik }\end{array}$ & $\begin{array}{l}<- \\
-- \\
\end{array}$ & $\begin{array}{l}\text { Mültecilere yönelik } \\
\text { alg1 }\end{array}$ & $-0,085$ & $-0,111$ & 0,021 & \begin{tabular}{|l|}
- \\
4,1 \\
24 \\
\end{tabular} & $* * *$ \\
\hline Davranissal niyet & $\begin{array}{ll}<- \\
-- \\
\end{array}$ & $\begin{array}{l}\text { Destinasyona yönelik } \\
\text { kişilik }\end{array}$ & 0,074 & 0,061 & 0,041 & \begin{tabular}{|l|}
1,8 \\
01 \\
\end{tabular} & $\begin{array}{l}0,0 \\
72 \\
\end{array}$ \\
\hline Davranıssal niyet & $\begin{array}{ll}<- \\
-- \\
\end{array}$ & \begin{tabular}{|l|} 
Destinasyona \\
yönelik memnuniyet
\end{tabular} & 0,599 & 0,564 & 0,039 & $\begin{array}{l}15, \\
304 \\
\end{array}$ & $* * *$ \\
\hline Davranıssal niyet & $\begin{array}{ll}<- \\
-- \\
\end{array}$ & $\begin{array}{l}\text { Destinasyona } \\
\text { yönelik tutum }\end{array}$ & 0,316 & 0,256 & 0,049 & \begin{tabular}{|l|}
6,4 \\
22 \\
\end{tabular} & $* * *$ \\
\hline Davranissal niyet & $\begin{array}{l}<- \\
-- \\
\end{array}$ & $\begin{array}{l}\text { Mültecilere yönelik } \\
\text { alg1 }\end{array}$ & $-0,011$ & $-0,012$ & 0,02 & $\begin{array}{l}- \\
0,5 \\
69 \\
\end{array}$ & $\begin{array}{l}0,5 \\
69 \\
\end{array}$ \\
\hline Davranissal_niyet & $\begin{array}{l}<- \\
--\end{array}$ & $\begin{array}{l}\text { Destinasyona yönelik } \\
\text { imaj }\end{array}$ & 0,099 & 0,075 & 0,044 & $\begin{array}{l}2,2 \\
34\end{array}$ & $\begin{array}{l}0,0 \\
25 \\
\end{array}$ \\
\hline
\end{tabular}

Yapısal modelde, destinasyonlarda mültecilere yönelik algıdan; destinasyon imajına destinasyona yönelik tutuma ve destinasyona yönelik davranışsal niyete giden yolun anlamlı olmadığı görülmüştür $(p>0,001)$. Bu sonuç mültecilere yönelik algının destinasyon imajını, tutumu ve davranışsal niyeti etkilemediğini ortaya koymaktadır. Diğer taraftan yapısal modelde, destinasyonlarda mültecilere yönelik algıdan; destinasyona yönelik memnuniyete ve destinasyona yönelik kişiliğe giden yolun anlamlı olduğu görülmüştür $(\mathrm{p}<0,001)$. Bu sonuç ise mültecilere yönelik algının destinasyon kişiliğini ve memnuniyeti etkilediğini ortaya koymaktadır. Memnun olmayan turistlerin davranışsal niyetinin de olumsuz olması beklenmektedir. Ancak burada söz konusu araştırmanın Gaziantep ilinde yapılması ve Gaziantep ilinin gastronomi ve kültür gibi farklı çekiciliklerinin olmasından dolayı mültecilere yönelik algının davranışsal niyeti etkilemediği düşünülmektedir. 


\section{SONUÇ}

Son yıllarda teknolojinin gelişmesi ve bunun sonucunda ulaşım olanaklarının artması nedeniyle turistik destinasyonlar arasında yoğun bir rekabet yaşanmaktadır. Destinasyonlar arasında yaşanan bu yoğun rekabet düşünüldügünde destinasyona yönelik imaj, memnuniyet, kişilik, tutum ve davranışsal niyet kavramları da daha fazla ön plana çıkarmaktadır. Bununla beraber 21. yüzyılın en önemli sorunlarından biri olan mültecilerin, destinasyon deneyimine etki edip etmediği turizmin en önemli konularından biri haline gelmiştir. Ancak bu konu gerek ulusal gerekse de uluslararası literatürde ihmal edildiği görülmüştür. Mültecilerle ilgili araştırmalara bakıldığında daha çok mültecilerin istihdamı (Görücü ve Akbıyık, 2015; Özkarslı, 2015), mültecilerin eğitimi (Yavuz ve Mızrak, 2016; Kağnıcı, 2017), mültecilerin sağlik durumu (Korkmaz, 2014; Önen, Güneş, Türeme ve Ağaç, 2014) gibi sosyal ve ekonomik konular üzerine odaklanıldığı görülmektedir. Gerçekleştirilen bu araştırmada ise Birleşmiş Milletler Eğitim, Bilim ve Kültür Örgütü'nün (UNESCO) Yaratıcı Şehirler Ağına girmeyi başarmış ve gastronomi başkenti olarak bir marka şehir olma yönünde ilerleyen Gaziantep ilinde mültecilere yönelik algıların destinasyona yönelik kişilik, imaj, tutum, memnuniyet ve davranışsal niyete etkisi ortaya konmuştur. Daha önce konu ile ilgili araştırma yapılmamış olmasından dolayı sonuçlar diğer araştırma sonuçları ile detaylı bir şekilde tartışılamamıştır. Araştırmada elde edilen sonuçlar ise aşağıda gösterilmiştir.

Mültecilere yönelik algının, destinasyona yönelik memnuniyeti negatif yönde ve anlamlı etkilediği görülmüştür (Bkz. Tablo 10). Bu sonuç Aratimur ve Akgündüz'ün (2018) gerçekleştirdiği araştırma sonuçlarıyla örtüşmektedir. Dolayısıyla turistik destinasyonlarda mültecilerin varlığının memnuniyeti olumsuz etkilediği gerçekleştirilen bu araştırmayla ortaya konmuştur.

Mültecilere yönelik algının, destinasyona yönelik davranışsal niyeti, tutumu ve imajı etkilemediği görülmüştür (Bkz. Tablo 10). Bu sonuç Zenker vd.,'nin (2019), gerçekleştirdiği araştırma sonuçlarıyla örtüşmemektedir. Zenker vd.,'nin (2019), gerçekleştirdikleri araştırma sonucunda mülteci krizinin, turist davranışını ve destinasyon imajını etkilediğini ortaya koymuşlardır. Gerçekleştirilen bu araştırmada ise destinasyonlarda mültecilerin varlığının destinasyon imajını, tutumu ve daha da önemlisi davranışsal niyeti etkilemediği ancak memnuniyeti olumsuz etkilediği görülmüştür. Mültecilere yönelik algıların, davranışsal niyeti ve imajı etkilemeyip memnuniyeti negatif etkilemesi sonucu oldukça dikkat çekicidir. Çünkü memnun olmayan turistlerin aynı zamanda davranışsal niyetinin de olumsuz olması beklenmektir. Ancak burada Gaziantep ilinin diğer çekiciliklerinden dolayı mültecilere yönelik algıların davranışsal niyeti etkilemediği düşünülmektedir.

Mültecilerin varlığının destinasyon imajını etkilemediği gerçekleştirilen bu araştırmayla ortaya konmuştur. Çünkü Gaziantep destinasyonu özellikle sosyal medyada mültecilerle değil gastronomi ve kültür çekicilikleriyle ön plana çıkmaktadır. Dolayısıyla oluşturulan bu olumlu imajın, mültecilerin önüne geçtiği düşünülmektedir. Başka bir ifadeyle Gaziantep ilinin hem mültecilere ev sahipliği yaptı̆g hem de gastronomisi ve kültürüyle olumlu bir destinasyon imajı oluşturduğu söylenebilir.

Mültecilere yönelik algının, destinasyona yönelik kişiliği negatif yönde ve anlamlı olarak etkilediği görülmüştür (Bkz. Tablo 10). Bu sonuç her destinasyonu kişilik özelliklerinin farklı olduğu sonucunu kanttlar niteliktedir. Daha önce mültecilerin destinasyon kişiliğine etki edip 
etmediğinin araştırılmadığı bilinmektedir. Dolayısıyla bu sonucunda gelecek araştırmalara referans olacağı düşünülmektedir.

Araştırma sonuçlarından hareketle turizm yöneticilerine ve turizm paydaşlarına sunulacak öneriler aşağıda verilmiştir.

- Araştırmanın bulguları, Gaziantep'teki özel ve kamu kurumları için oldukça yararlı olduğu düşünülmektedir. Turistlerin Gaziantep'in kişiliğini nasıl algıladığını bilerek, destinasyon için benzersiz bir kimlik geliştirebilir ve çekiciliği ile rekabet gücünü artırmak için bu kimliğin etrafında pazarlama kampanyası tasarlanabilir.

- Turizm uluslararası bir hareket olduğu için destinasyonlardaki mülteci sorunun uluslararası toplumla hareket edilerek ortak hareket edilmesi önerilmektedir.

- Destinasyonlarda turizmin sürdürülebilir olması için yerel yönetimlerin turistik bölgelerdeki denetimleri artırmaları önerilmektedir.

- Mültecilere kamplarda Türk kültürü ve tarihinin öğretilmesi önerilmektedir.

- Mültecilere dil, tarih, kültür ve turizm gibi konularda eğitim verilebilir.

- Gaziantep'in marka bir şehir olma avantajını dezavantaja çevirmemesi hususunda tüm paydaşlara büyük görev düşmektedir. Unutulmamalıdır ki olumlu bir imaj oluşturmak sadece kamu kurumlarının görevi değil tüm paydaşların görevidir.

Araştırmaya bağlı olarak benzer konuda çalışacak araştırmacılara ise aşağıda belirtilen öneriler sunulabilir:

- Sonuçlar, destinasyonun benzersiz kişilik özellikleriyle tanımlandığını göstermektedir. $\mathrm{Bu}$ nedenle, mültecilerin yoğun olduğu diğer destinasyonlar için destinasyona özgü uygulanabilir farklı kişilik ölçeklerin geliştirilmesi önerilebilir.

- Gelecekteki araştırmalar, turistik destinasyonlarda farklı turist tiplerinin mültecileri nasıl algıladıklarını araştırabilir.

- Mültecilerin bulunduğu farklı destinasyonlarda özellikle Yunanistan'da mültecilerin destinasyonlara etkisi araştırılıp bu araştırma sonuçlarıyla karşılaştırma yapılabilir.

- Araştırmacılara farklı dillere ve daha geniş örnekleme odaklanmış çalışmalar önerilebilir.

- Bu tür çalışmaların turizmin geleceği için tekrarlanması gerektiği düşünülmektedir. Dolayısıyla farklı coğrafya ve kültürlerde araştırmanın tekrarlanması ve sonuçların karşılaştırılması önerilmektedir.

\section{KAYNAKÇA}

Akdoğan, M., ve Sağıroğlu, C. (2017). İtalya ve Suriyeli mülteciler: Avrupa'nın zorlu sınavı. Ekonomi, Politika ve Finans Araştırmaları Dergisi, 2(2), 146-161.

Akkılıç, M. E. ve Varol, İ. (2015). Turist algılarının davranışsal niyetler üzerindeki etkisi: Edremit Körfezi Örneği. International Review of Economics and Management, 3(1), 14-38.

Aratimur, V. ve Akgündüz, Y. (2018). Yabancı turistlerin destinasyon seçimine sığınmacıların etkisi: Türkiye'ye yönelik bir araştırma. Alanya Akademik Bakış, 2(2), 157-175.

Byrne, B. (2016). Structural Equation Modeling With AMOS. New York: Routledge, https://doi.org/10.4324/9781315757421

Çelik, S., Öztürk, E. ve Coşkun, E. (2019). Turistlerin destinasyon kişiliği ve kalite algılarının tekrar gelme eğilimleri üzerindeki etkileri: İspanya/Endülüs Bölgesi'nde bir araştırma. Journal of Tourism and Gastronomy Studies, 7 (1), 340-357.

Çokluk, Ö., Şekercioğlu, G., ve Büyüköztürk, Ş. (2010). Sosyal Bilimler İçin Çok Değiş̧kenli İstatistik SPSS ve LISREL Uygulamaları. Ankara: Pegem Akademi. 
De Nisco, A., Mainolfi, G., Marino, V. and Napolitano, M. R. (2015). Tourism satisfaction effect on general country image, destination image, and post-visit intentions. Journal of Vacation Marketing, 21(4), 305-317.

Endrich, M., and Michel, S. (2018). The good tourist, the bad refugee and the ugly German: Xenophobic activities and tourism (No. 16). ILE Working Paper Series.

Görücü, İ., ve Akbıyık, N. (2015). Suriyeli sığınmacılar ve istihdam problemleri. Birey ve Toplum Sosyal Bilimler Dergisi, 5(1), 63-94.

Hallab, Z., and Kim, K. (2011). The Effects of Nonresidents' Geographical and Cultural Distance on a Tourist Destination's Image. In Advances in Hospitality and Leisure (pp. 131-152). Emerald Group Publishing Limited.

Ivanov, S., and Stavrinoudis, T. A. (2018). Impacts of the refugee crisis on the hotel industry: Evidence from four Greek islands. Tourism Management, (67), 214-223.

İç İşleri Bakanlığ1 Göç İdaresi Genel Müdürlüğü, (2013). http://www.goc.gov.tr/files/_dokuman19.pdf

İç İşleri Bakanlığı Göç İdaresi Genel Müdürlügüu, (2019). http://www.goc.gov.tr/icerik6/gecicikoruma_363_378_4713_icerik (Erişim tarihi: 07.06.2019)

Kağnıcı, D. Y. (2017). Suriyeli mülteci çocukların kültürel uyum sürecinde okul psikolojik danışmanlarına düşen rol ve sorumluluklar. Ilköğretim Online, 16(4), 1768-1776.

Kara, P. ve Korkut, R. (2010). Türkiye'de göç, iltica ve mülteciler. Türk İdare Dergisi, 467:153-162.

Kavuk, M. (2015). Yabancılar hukukunda vatansızlar ve mülteciler. İstanbul Ticaret Üniversitesi Sosyal Bilimler Dergisi. 14(28), 179-191.

Kelloway, E. K. (1998). Using LISREL For Structural Equation Modeling: A Researcher's Guide. California: Sage Publications.

Korkmaz, A. Ç. (2014). Sığınmacıların sağlık ve hemşirelik hizmetlerine yarattığı sorunlar. Sağlık ve Hemşirelik Yönetimi Dergisi, 1(1), 37-42.

Melotti, M. (2018). The Mediterranean Refugee Crisis: Heritage, Tourism, and Migration. New England Journal of Public Policy, 30(2), 1-26.

Önen, C., Güneş, G., Türeme, A., ve Ağaç, P. (2014). Bir mülteci kampında yaşayan Suriyelilerde depresyon ve anksiyete durumu. Akademik Sosyal Araştırmalar Dergisi, 2(6), 223-230.

Özgüneş, E. R., Açıksözlü, Ö. ve Bozok, D. (2016). Destinasyon İmajı Boyutlarından Değerlendirici İmajın Yerleşik Yabancıların Yerleşim Yeri Seçimlerinde Etkisi: Bodrum, 17. Ulusal Turizm Kongresi, Bodrum.

Özkarslı, F. (2015). Mardin'de enformel istihdamda çalışan Suriyeli göçmenler. Birey ve Toplum Sosyal Bilimler Dergisi, 5(1), 175-192.

Pappas, N. and Papatheodorou, A. (2017). Tourism and the refugee crisis in Greece: Perceptions and decision-making of accommodation providers. Tourism Management, (63), 31-41.

Pechlaner, H., Lange, S. and Raich, F. (2011). Enhancing tourism destinations through promoting the variety and uniqueness of attractions offered by minority populations: an exploratory study towards a new research field. Tourism Review, 66(4), 54-64.

Seetaram, N. (2012). Immigration and international inbound tourism: Empirical evidence from Australia. Tourism Management, 33(6), 1535-1543. 
Souiden, N., Ladhari, R. and Chiadmi, N. E. (2017). Destination personality and destination image. Journal of Hospitality and Tourism Management, (32), 54-70.

Yavuz, Ö., ve Mızrak, S. (2016). Acil durumlarda okul çağındaki çocukların eğitimi: Türkiye' deki Suriyeli mülteciler örneği. Göç Dergisi, 3(2), 175-199.

Zenker, S., Von Wallpach, S., Braun, E., and Vallaster, C. (2019). How the refugee crisis impacts the decision structure of tourists: A cross-country scenario study. Tourism Management, (71), 197212. 